ESPAÇO TEMÁTICO - SERVIÇO SOCIAL: FORMAÇÃO, TRABALHO PROFISSIONAL E

TENDÊNCIAS TEÓRICAS CONTEMPORÂNEAS

\title{
Cultura Hip-Hop e Serviço Social: a arte como superação da invisibilidade social da juventude periférica $^{1}$
}

\author{
Daniel Péricles Arruda ${ }^{1}$ \\ http://orcid.org/0000-0002-8347-8215 \\ ${ }^{1}$ Universidade Federal de São Paulo, Departamento de Saúde, Educação e Sociedade, Curso de Graduação em Serviço Social, Santos, SP, \\ Brasil
}

\section{Cultura Hip-Hop e Serviço Social: a arte como superação da invisibilidade social da juventude periférica}

Resumo: Objetiva-se apresentar uma leitura crítica sobre as interfaces entre a invisibilidade social da juventude periférica e a arte, especificamente com a cultura hip-hop. A partir da abordagem marxista e da linha metodológica da história oral, foram entrevistados três sujeitos integrantes dessa cultura. A pesquisa realizada demostra ser importante que essa arte esteja articulada à cotidianidade dessa juventude, com base em suas sociabilidades territoriais significativas de ações políticas e expressões afetivas.

Palavras-chave: Cultura hip-hop. Invisibilidade. Juventude Periférica. Reconhecimento. Serviço Social.

\section{Hip-Hop Culture and Social Work: the art to overcome the social invisibility of peripheral youth}

Abstract: This article aims to present a critical reading on the interfaces between social invisibility of peripheral youth and the art, hip hop culture. Three subjects were interviewed using the marxist approach and oral history methodology. The research demonstrates that it is important that this art is articulated to the daily life of these youth, based on their significant territorial sociabilities of political actions and affective expressions.

Keywords: Hip-Hop Culture. Invisibility. Peripheral Youth. Recognition. Social Work.

Recebido em 10.05.2019. Aprovado em 17.09.2019. Revisado em 26.11.2019.

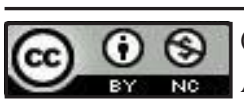

(C) O(s) Autor(es). 2020 Acesso Aberto Esta obra está licenciada sob os termos da Licença Creative Commons Atribuição-NãoComercial 4.0 Internacional (https://creativecommons.org/licenses/by-nc/4.0/deed.pt_BR), que permite copiar, distribuir e reproduzir em qualquer meio, bem como adaptar, transformar e criar a partir deste material, desde que para fins não comerciais e que você forneça o devido crédito aos autores e a fonte, insira um link para a Licença Creative Commons e indique se mudanças foram feitas.
} 


\section{Introdução}

A finalidade deste artigo é apresentar os resultados sobre as interfaces entre a trajetória de vida da juventude periférica, que encontra na arte, na cultura hip-hop, uma forma de lidar com a invisibilidade social e construir outros sentidos para suas experiências sociais.

Entende-se por juventude periférica aquela que ocupa desigualmente uma determinada posição e condição social. Seja aquela que esteja vinculada concretamente às periferias das cidades, ou aquela que não reside nas periferias, mas vivencia processos de invisibilidade social frutos dessas condições, considerando, inclusive, suas singularidades epluralidades.

Percebe-se que, para parte significativa dessa juventude, a arte é um modo de vida, uma experiência grupal construtora de identidades; é também uma forma de enfrentamento político das desigualdades sociais e do modo violento e indiferente ao qual é submetida em muitos contextos. São questões importantes para o Serviço Social - em razão de sua luta pela efetivação de direitos e respeito às diversidades -, e para a cultura hip-hop - devido à potência cultural educativa e reflexiva.

\section{Os procedimentos metodológicos}

A pesquisa realizada teve por base o aporte qualitativo da história oral com foco temático. Foram entrevistados três sujeitos que fazem parte da cultura hip-hop. Dois são jovens com média de idade de 26,5 anos - ambos residentes no distrito de Brasilândia, zona norte da cidade de São Paulo/SP, território escolhido em razão da significativa atuação artística dos jovens entrevistados nesse local -, e um sujeito adulto - com idade aproximada de 50 anos, que reside no município de São Bernardo do Campo/SP (região metropolitana) -, por desenvolver atividades através da cultura hip-hop no estado de São Paulo, além de ser reconhecido nacional e internacionalmente, em razão de sua militância na área e seu profundo conhecimento geracional e histórico sobre o tema.

A pesquisa desenvolvida partiu das seguintes questões norteadoras: De que modo a juventude periférica se apropria da arte - na perspectiva crítica - como meio de superação da invisibilidade social? Quais são as interfaces entre a arte - na perspectiva crítica - e a invisibilidade social, no tocante à visão de humanidade e de mundo da juventude periférica?

Desse modo, o trabalho de campo foi fundamental para conhecer as condições territoriais dos sujeitos entrevistados, pois, de acordo com Portelli (1997) e Martinelli (1999), de fato, por meio da história oral, a qual exige a ida a campo, é possível conhecer a experiência e memória do indivíduo, aprofundando, por meio do diálogo, para conhecer os impactos dessas vivências em suas vidas².

\section{Os sujeitos da pesquisa: donos da palavra}

Primeiramente, entrevistamos o jovem Felipe, mais conhecido como Bobina, de 25 anos de idade, nascido e criado no distrito de Brasilândia. Ele é MC, músico, compositor, integrante do grupo Quilombrasa. Na época da pesquisa, era estudante do curso de Serviço Social. Bobina começou a se envolver com a arte por meio da música, ainda criança:

Foi através da minha mãe. Então, desde que eu nasci... Minha mãe é compositora, né?! É compositora, compositora sertaneja. Então, desde que eu me lembre, ela tinha essa batalha dela. Ela fazia as músicas dela. Então, a gente conhecia muito a obra dela, assim, em casa, ela cantando pra gente. (depoimento de Bobina).

O menino que via e ouvia a sua mãe cantando, começou, aos 8 anos de idade, a escrever as suas primeiras poesias e aprender a tocar violão. Eram produções feitas para ele próprio, naquele contexto, sem pretensões de apresentá-las. Após quase 10 anos, Bobina apresentou publicamente a sua arte no Sarau da Brasa, em sua comunidade.

Quando vem o Sarau da Brasa, que aí todas essas coisas que estavam engavetadas [poesias e composições musicais], inclusive da minha mãe, essas obras que estão ali, ganham um espaço de troca, de visualização da galera, que é já, depois, ali, com 17, 18 anos, por ali, assim... (depoimento de Bobina). 
$\mathrm{Na}$ adolescência, envolveu-se com a cultura hip-hop, tendo por referência a sua participação no projeto Criança Esperança, onde aprendeu a fazer produções musicais e pode apresentar e desenvolver sua produção literária acumulada, tirando-as da "gaveta". Seu primeiro trabalho com música foi com o grupo Quilombrasa. Na sequência, desenvolveu seu trabalho solo, já sendo chamado de Bobina:

Cara, esse nome, é coisa que vem de infância. É... [canto suave de um pássaro que o faz interromper a fala e observar] Mas eu... Ele se transformou e eu não sei de onde veio essa transformação, porque começou como Bobby Generic, que era do Fantástico Mundo de Bobby, que era pequenininho, que falava um monte de besteira... Viajando... E os moleques um pouco maior tinham mania de dar apelido, e eu, Bobby, Fantástico Mundo de Bobby. Mas, até chegar em Bobina, mano, eu não faço ideia como essa coisa... Como se transformou nisso aí, pra chegar no Bobina. Não faço ideia mesmo (depoimento de Bobina).

Diferentemente do personagem do desenho, Bobina tem encontrado na arte uma forma de alimento para sua consciência e um caminho para realizar os seus sonhos concretamente. O Fantástico Mundo de Bobina (parafraseando o título do desenho citado em seu relato) é real, e não ilusório. O seu "mundo" é o local onde se desenvolveu e se desenvolve, principalmente por meio da cultura hip-hop.

O outro jovem da pesquisa é Israel, mais conhecido como Mano Réu, com 28 anos de idade, também é morador, desde os seus 10 anos de idade, do distrito de Brasilândia; possui ensino técnico em Comunicação, é MC, escritor e educador social. É também organizador de eventos educativos e culturais; participa de várias atividades na cultura hip-hop em São Paulo e em outros Estados do País, e mantém o seu próprio coletivo cultural: Literatura Suburbana.

Assim como Bobina, Mano Réu também teve a família, sua mãe, como influência, no campo da arte. Para ele, a arte:

Tem muita relação com a família, com a minha mãe e tal. Eu brinco falando que eu sou da geração do Funky, né?! Como hoje, daqui uns anos a molecadinha nova vai falar que é também, né?! Sou de uma geração onde meus pais se encontraram no baile, eram bailes frequentados por pessoas negras de periferia, né?! E que talvez tinham os mesmos preconceitos que nós temos hoje, que o Funk enfrenta, né?! (depoimento de Mano Réu).

O mundo funky [raiz] dos pais de Mano Réu - que não é o mesmo funk de hoje - é um dos seus pilares identitários. Esses pilares são os mesmos que norteiam a construção de seu pseudônimo:

É que o pessoal pensa que é o maior "pá, né?!” Que nada, velho! Tinha um baixista lá na igreja, velho, que é o Marcão, ai ele falou: "Mano?! Eu vou te chamar de Réu”. Aí eu falei: Por quê? Ele disse: "Não! É que Israel é muito grande, Rael também. Então, eu vou resumir tudo e vai ficar Réu”. Eu disse: Puta! Da hora. E, aí, foi. E aí ficou até hoje, e pra sempre, né?! Réu, então, não é nada do que o pessoal pensa. "É uma crítica... É que somos todos réus da sociedade.” Não! Não! Não! Não! É só uma abreviação (depoimento de Mano Réu).

O terceiro sujeito da pesquisa é Joaquim, conhecido como King Nino Brown. Pernambucano, veio para São Paulo no dia 14 de outubro de 1974. Residindo primeiramente no bairro de Pinheiros, na Praça Benedito Calixto, durante um ano, em 1975, mudou para São Bernardo do Campo, para morar na Favela do Jardim Calux. É presidente da Zulu Nation Brasil desde 2002, ano de sua inauguração. Essa instituição é uma ramificação da Zulu Nation, fundada em 12 de novembro de 1973, nos Estados Unidos, por Afrika Bambaataa, com o objetivo de desenvolver oficinas, palestras, seminários e encontros para a divulgação e o fortalecimento da cultura hip-hop, principalmente para a juventude periférica.

King Nino Brown, no período da pesquisa com 53 anos de idade, era coordenador da Casa do Hip-Hop de São Bernardo do Campo, onde desenvolvia vários projetos, por meio da cultura hip-hop, com jovens de várias cidades do estado de São Paulo, bem como de outras regiões do País.

King Nino Brown faz parte da cultura hip-hop no Brasil desde sua origem, nos anos 1980. Seu envolvimento com a arte deu-se antes mesmo da cultura hip-hop, ou seja, "[...] minha trajetória começa no Baile Black, quando se ouve James Brown. Ali foi... Eu falo sempre de James Brown, porque foi o meu início" (depoimento de King Nino Brown).

Ao ter contato com a cultura black, ainda em sua adolescência, ele se encantou. "Eu comecei no Baile Black, aos 15 anos. Aos 15 anos eu falei: 'É isso aqui que eu vou fazer!'. Foi na Sedinha do Calux, um time de futebol de São Bernardo do Campo, mas [o time] não existe mais!" (depoimento de King Nino Brown). 
King Nino Brown assim narra a origem de seu pseudônimo: "Por que King Nino Brown? É a construção de um nome. É a construção de uma história, entendeu?!". Por isso, para melhor entender essa construção, os detalhes e a importância de sua narrativa, na íntegra, ele conta:

Então! Meu nome é Joaquim, né?! Joaquim de Oliveira Ferreira. Meu pai que me registrou com esse nome, minha mãe não gostou e colocou o apelido de Nino. Porque, em Pernambuco, Nordeste, assim, sempre te chamam pelo apelido. Nino, é de menino. Aí eu fui... [Esse café tá frio, mano?! (Risos). O café tomado pelo pesquisador]. Eu fui, é... Eu comprava disco na "Poster Som" e nesse dia o Toni Tornado estava lá. Às vezes, eu até esqueço de contar essa história, só quando perguntam... Aí eu comprei um vinil "Os Bailes Black no Palmeiras". Nesse dia, eu comprei esse vinil. Ai na hora que eu cheguei na loja [disse-me Toni Tornado]: "Ao Nino ai que também gosta do James Brown”. Aí, começamos a conversar. Isso há vinte anos atrás, hein?! Eu tinha uns 30 anos [de idade], tempo pra caralho! [risos]. Foi na "Poster Som", na Galeria ali, no Subsolo, com o Pelé. Primeiro ficamos na loja, só trocando ideia, aí o Pelé rolando o som do James Brown, e nós conversando, e pá! E ele contando as coisas e falando. Aí saímos da loja e fomos tomar um guaraná, sentamos ali e pá! Normal, trocando ideia! Na hora que ele foi embora eu pedi pra ele dar um tag [nesse sentido, dar um autógrafo] no meu disco, ele escreveu uma pá de coisa lá... "Ao Big Nino Brown". Porque o Pelé falou, "Põe Brown aí no meio". Então, ele foi lá e escreveu, e tudo. Aí ficou, Nino Brown. Desse dia em diante, mudou tudo. Aí, em 1994, quando eu conheci, quando eu mandei a carta para Zulu Nation, e em 1999 quando o Bambaataa veio aí eu levei um disco, um disco que eu peguei o endereço da Zulu, aí foi quando começou o King, King Nino. King porque eu sou batizado na Zulu Nation. E quando o rei Zulu, nascia Zulu, somos reis e rainhas, né?! Então, por isso que tem esse nome King Nino Brown. É dessa construção. King da Zulu, Nino da minha mãe, e Brown de James Brown, numa conversa com Toni Tornado. E quando eu encontrei com ele também... Eu tenho um vinil dele, que eu falei assim: "Esse vinil eu vou guardar pra ele autografar o próprio vinil”. Só que esse vinil é plastificado. É um vinil bem antigo. Então, você tem que tirar o plástico, aí fica só o papel. Eu tive que fazer isso porque é um honra, né?! Aí quando teve o "Black Fashion Week", ai ele participou do "Soul Train" [Programa de TV]. Olha como são as coisas, o Toni Tornado fazia o "Don Cornelius" [Personagem], ele que ficava na frente, como se fosse o baile "Soul Train”, chegando e dançando, né?! Entramos eu e o Nelsão [Nelson Triunfo]. Cumprimentávamos o Toni Tornado, os outros vinham dançando e pá, ai no final eu levei o vinil, e falei pra ele, "Olha! Isso aqui estava guardado há muito tempo" dá um tag aí. Aí ele fez e tiramos uma foto (depoimento de King Nino Brown).

A busca e construção de um nome são marcantes para o sujeito, pois há nomes que libertam e outros que aprisionam. Os nomes têm suas cargas simbólicas, afetivas e históricas. A questão não é apenas a estética e nem a sonoridade nominal, mas o sentido que lhe é atribuído, por quem chama e por quem é chamado. Às vezes, o apelido tem mais representatividade do que o próprio nome formal, pois há apelidos que expressam reconhecimento e carinho, e outros que expressam ódio e rejeição. O nome implica também o modo como olhamos para o outro.

\section{Um diálogo entre a cultura hip-hop e o Serviço Social}

A cultura hip-hop, por ter suas origens no grupo e na rua, é por excelência audaciosa, corajosa e criativa, por isso apresenta o cotidiano repensado (HELLER, 1972b); mostra o discurso da juventude periférica permeada de sentimentos, desejos e denúncias. Porém, se não atentarmos ao que o rap, o DJ, o breaking, o graffiti e o conhecimento - todos elementos da cultura - têm a nos dizer, pode-se desclassificá-la como tal.

Já o Serviço Social é compreendido aqui como uma profissão voltada para o atendimento das humanidades, ou seja, das pessoas em suas mais diversas situações sociais, que demandam a efetivação de seus direitos. Porém, no caso brasileiro, por ser uma sociedade socialmente desigual, temos um grupo mais expressivo, em razão de sua condição de classe social, das relações de raça/cor e gênero. Importante dizer que essa profissão também é construtora de conhecimento, de reflexões, e um espaço de educação social e política.

Assim, nesse cruzamento entre a cultura hip-hop e o Serviço Social, identificamos uma perspectiva voltada para a formação crítica e reflexiva da sociedade capitalista, que valoriza o ser humano. Esse cruzamento apresenta um posicionamento político legítimo e contundente. Porém, por serem espaços de formação, um profissional e o outro cultural, aspectos majoritários são comuns e contradições não deixam de fazer parte de seus posicionamentos. 
Tais posicionamentos partem do concreto, das relações sociais e experiências cotidianas. Por essa razão, King Nino Brown, ao analisar sua realidade político-territorial, apresenta, também, outra esfera, que constitui os campos político e governamental das relações. "Porque é a política que nos rege. É a política que faz parte das nossas vidas. Se a gente tivesse um governador do povo, um governador legal junto com a gente. Tá difícil!" (depoimento de King Nino Brown).

Se na atualidade a cultura hip-hop é mais visível, aceita socialmente e aparente nos meios de comunicação, antes não era assim, em razão do preconceito alimentado pelo estigma, ou seja, pela estética, pela raça/ cor, pela classe social, pelos signos dessa cultura, tomados como coisa de "bandido".

Como a cultura hip-hop é um espaço de educação social e política, assim como o Serviço Social também o é, consideramos ser possível que o Serviço Social se utilize dessa cultura para duas principais ações. A primeira refere-se à aproximação de sujeitos por meio dessa arte; isto é, como mediação, linguagem e instrumentalidade da prática profissional do/a assistente social ${ }^{3}$. A segunda refere-se aos ensinamentos dessa cultura para ler criticamente a vida social e, até mesmo, como contribuição no processo de formação profissional, pois essa cultura, a partir de todos os seus elementos, pode auxiliar e mediar o entendimento sobre a relação entre teoria e prática, principalmente no trabalho desenvolvido com crianças, adolescentes, jovens e suas respectivas famílias".

Por esses motivos, é preciso reconhecer a grandeza e o poder que a cultura hip-hop tem no Brasil.

Eu vou falar mais fundo: o hip-hop tem força para eleger o presidente, tá entendendo?! Tem um grupo aí que se essa pessoa saísse candidata ela ganhava, mano, estourado, você sabe até quem é, eu não vou nem dizer o nome... E como prefeito [também]... Mas só que eu não sei o que acontece, mano. A gente tem sim, força pra eleger o presidente, você acredita ou não? [Sim]. Se a gente tivesse centralizado e pá. Pra você ver, hip-hop no Brasil inteiro, um candidato à Presidência da República do hip-hop (depoimento de King Nino Brown).

A política, aqui considerada enquanto relações entre pessoas e como espaço de debate e embates de ideologias, é também relacionada ao campo partidário de representação identitária, a partir de alguém como "Nós", alguém que tenha entendimento das demandas populares, bem como a própria população. King Nino Brown acredita que:

[...] O entendimento tem que estar interligado. Os Panteras Negras o que foi que eles fizeram? Eles leram a Constituição pra poder combater o poder. "Eu posso andar armado a tal distância da polícia!". Foi isso que eles fizeram. Foi aí que entrou uma lei que ninguém poderia andar armado. Então, é isso. Eu li a Constituição e vi lá os direitos que nós temos, de ir e vir na hora que eu quiser. Mentira, né?! Não existe isso aí. Agora imagina o jovem começando a ler a Constituição, também?! Eu sei que é chato pra caramba aquilo ali, mas leia o artigo primeiro [Parágrafo único], “Todo o poder emana do povo!”. Tá lá, éo voto, mano. Agora, imagina se povo, pô... "Nós somos a maioria, gente. Vamos votar em fulano que vai nos representar. Se não representar a gente tira ele”. É isso cara! (depoimento de King Nino Brown).

Nessa concepção, a partir do entendimento da realidade, é possível posicionar-se de maneira efetiva. Como o "povo" é uma unidade diversa em valores e visões, o entendimento dos direitos é uma questão que faz King Nino Brown indagar:

Porque [o povo] não tem o entendimento?! O povo ainda não acordou pra isso. O povo acha que numa comunidade tendo um barzinho, um sambinha, já tá bom! Certo?! [silêncio prolongado]. É isso que acontece... Joga-se lixo na rua, os entulhos e tudo mais. Já pensou se: "Olha, a gente tá precisando de uma caçamba aqui", e se todo mundo se reunisse?! Para que servem as Associações de Bairro? Era pra dar curso de eletricista, encanador, curso de corte costura. Você vê isso hoje? Você não vê. Você vê o quê? Muitas ONGs que pegam verbas federais, mas não investem, por isso que tem tanta treta aí, né?! (depoimento de King Nino Brown).

Para King Nino Brown, "entendimento é absorver [a realidade] para depois transformar, certo?!". Isto é, "Você sabe que a água engasga?! Se você tiver com muita sede e você despejar de uma vez... Então tem que entender que o conhecimento é tudo, e o hip-hop, ele tem essa força, só que precisa entender, sabe?! E estamos chegando lâ" (depoimento de King Nino Brown).

Desse modo, nessa encruzilhada constituída pela cultura hip-hop e o Serviço Social existem pontos convergentes que possibilitam modificar o modo de apreender as diversificadas manifestações da questão social e os processos de subjetivação da juventude periférica. 
A cultura hip-hop e o Serviço Social têm muito que contribuir um com o outro. A curiosidade/necessidade de saber o que o outro é, ou de ter o seu reconhecimento, pode contribuir para o debate. Já o preconceito e o desinteresse podem obstruir o diálogo. A intenção não é cientificar a cultura hip-hop, tampouco colocar o Serviço Social como avaliador dessa cultura. A intenção é favorecer a troca, o entendimento - como nos disse King Nino Brown -, pois, de todas as profissões, o Serviço Social é uma das que mais lida direta e cotidianamente com as questões apresentadas por essa arte. E, de todas as artes, a cultura hip-hop está entre as que mais desenvolve ações relacionadas ao objeto de estudo e intervenção do Serviço Social.

\section{A arte na perspectiva crítica}

Na concepção marxiana, a arte tem por finalidade contribuir para o desenvolvimento do humano-genérico, em sua visão de humanidade e mundo. Nessa lógica, a arte não compete com o trabalho, e, sim, corrobora para a formação do humano (MARX, 2004). Desse modo, a arte faz parte do desenvolvimento do ser.

Em Lukács (2010, p. 267): “A tarefa exclusiva da arte seria a de tomar posição nas lutas da época, da sociedade, das classes sociais; de favorecer a vitória social de uma determinada tendência, a solução de um problema social”. A arte, então, tem uma função social ativa, e sua crítica está em seu posicionamento político, que visa a ação, transformação, ou seja, uma arte revolucionária e reflexiva.

A arte tanto em entretenimento, diversão, é paz de espírito e tal. Acho que o uso dela também é nesse sentido, de reflexão. Principalmente, quando a gente usa ela [a arte] pra educação, né?! Que em muitas vezes eu faço e tal [...] Esse semestre eu dei um curso de produção musical, pra galera do Fábrica de Cultura. Estávamos discutindo a música, e como isso perpassa a sociedade. Então, alguns ali vão ser produtores musicais, porque o moleque tem o dom, mas outros não, outros vão tá lá só pra refletir, mesmo. Olha como a música é louca, como um CD é importante na nossa vida. Então, a música e a arte não é só uma coisa aleatória, ela faz todo sentido. Acho que é pra isso que existe, é... De focar o trabalho artístico e tal, quando é pra educação, focar nesse lance. Não de profissionalismo artístico... Técnico e tal, pode também, mas de reflexão sobre a pessoa, pra ela se achar, né?! (depoimento de Mano Réu).

E, para se achar, é preciso viver, ter liberdade e reais condições de escolha. Certamente, para muitos, a "trilha sonora da periferia, o rap foi o responsável pela 'educação sentimental' dos negros pobres, que constituem a grande maioria do sujeito periférico" (FREDERICO, 2013b, p. 241, grifo do autor).

Por meio dessa cultura, muitos jovens conseguem desenvolver-se na arte e também no campo do trabalho; a arte como forma de sobrevivência e renda. Por meio dessa arte, também é possível criar laços afetivos e comunitários:

Agora assim, eu posso até sair na melhor revista do mundo, eu posso até dar entrevista para a melhor TV do mundo, posso até... Mas eu nunca vou deixar de ser eu. Não consigo me ver trancafiado, sabe?! Tipo, porque o artista vive da imagem dele, então, tem certos lugares que a gente tem que ir, e cobrar. E como a nossa luta, eu falo assim, é a luta do povo, a gente tem que saber diferenciar as coisas, até que ponto nós podemos cobrar? Precisamos sobreviver, sim, mas até que ponto eu posso, realmente, criar essa parede de vidro. Você me vê, mas você não pode me tocar, né?! (depoimento de King Nino Brown, negrito do autor).

O rap serviu e serve para a "educação sentimental" de milhares de jovens, bem como foi responsável pela educação política deles. Isso fica evidente nas letras das músicas, nos discursos realizados pelos rappers, na postura adotada frente às inquietações da vida, como pobreza, preconceito, racismo e violência. Esse estilo musical não dá voz à juventude periférica, e sim possibilita algo que deveria ser comum a ela: o espaço para falar e ouvir.

Agora, fazendo arte, eu vejo uma mudança aí, da forma como as pessoas me veem, mas também como eu me vejo no mundo; acho que essa é a questão, depois que eu começo a fazer [arte], eu começo a me ver diferente no mundo, assim, de uma forma... É... Não só de me enxergar, mas também de ver o outro também (depoimento de Bobina).

A arte vai para além de sua produção e exposição, pois trata-se de uma relação entre sujeitos, dos encontros. Por isso que Bobina, em sua trajetória de vida permeada pela arte, percebeu a diferença do olhar das pessoas e do seu próprio olhar direcionado a si próprio e aos outros. 
[...] Porque, antes, eu não prestava atenção, não. Assim... [as pessoas] passavam direto pelos meus olhos, depois, eи comecei a fazer essas coisas [poesias e rap], eи comecei a dar mais valor, assim, para o que os outros faziam também. E eu queria que os outros me dessem valor. Aí eu fiquei mais seguro, eu era muito inseguro antes, cara! (depoimento de Bobina).

A falta de valor, de reconhecimento, provoca insegurança, pois a vida torna-se frágil. Nesse depoimento, percebe-se que a arte não lhe deu um caminho, mas condições para que o jovem construísse a sua história, por meio do valor alheio e de sua autossegurança, proporcionando-lhe valor próprio, valor recíproco. Esse valor é produzido na relação de um/a jovem com o/a outro/a, na relação de/entre grupos, assim como foi nas origens da cultura hip-hop.

Por meio da música rap, muitos jovens formaram grupos, organizaram-se socialmente, trocando vivências com jovens de outras comunidades; foram se organizando territorialmente; na maioria das vezes, sem apoio do poder público. Essas questões são influenciadas pelo desenvolvimento territorial, por isso, comumente, o termo "periferia" é muito mencionado nas letras de rap como local de existência, permanência e resistência. Analisando o termo:

\begin{abstract}
Os bairros populares, situados às margens da cidade, não eram chamados de periferia. O batismo ocorreu inicialmente na sociologia urbana para designar um espaço de carência, marginalidade, violência e segregação. Daí o termo foi adotado pelos movimentos culturais para, em seguida, ser incorporado pelas políticas públicas que visam à inclusão social - inclusão, diga-se, restrita à participação no mercado de bens de consumo. Ultimamente, a eterna sanguessuga, a indústria de entretenimento, passou a enfocar a periferia em filmes, novelas, anúncios publicitários etc. (FREDERICO, 2013b, p. 240).
\end{abstract}

Caracteriza as grandes cidades brasileiras esse formato geográfico e relacional: "centro-periferia" embora existam outras formações: "periferia-no-centro", "centro-da-periferia", "periferia da periferia", "centro do centro". A verdade é que, comumente, em muitos contextos, o termo "periferia" é compreendido como um adjetivo que desqualifica locais e pessoas. Já na cultura hip-hop, esse termo simboliza a posição política e discursiva dos sujeitos.

\title{
A "desfetichização" por meio da arte
}

Numa perspectiva teórico-conceitual, Löwy, Duménil e Renault (2015, p. 62) afirmam que “[...] o conceito de 'fetichismo' designa uma ilusão ligada à forma fenomenal do valor". A ilusão é tomada como realidade, a realidade da ilusão; determinante, na avaliação do valor.

Para os autores, essa questão, em Marx: “[...] se empenha também em mostrar que o fetichismo constrói uma espécie de nebulosa própria ao modo de produção capitalista, que desaparecerá na sociedade comunista". (LÖWY; DUMÉNIL; RENAULT, 2015, p. 62).

Em Lukács, "a análise do fetichismo foi desenvolvida sob a forma da filosofia da reificação, segundo o qual os processos sociais transformam o trabalho humano, e todos os elementos do mundo social e natural, em coisa". (LÖWY; DUMÉNIL; RENAULT, 2015, p. 62-63).

A arte é muito mais do que a questão do consumo. Ai eu falo do consumo mesmo, "Caraca! Aquele cara é monstro, aqui na nossa quebrada, tá estouradão aí. Que louco!” Porque esse sucesso aí, velho, é um para três milhões, então se for olhar, não tá funcionando, velho. Porque se é um para essa massa, proporcionalmente, não tá funcionando. Mas a arte, além desse um que pode representar esse monte, pode ser também, né?! De trazer à tona tudo isso, a arte tem esse poder, né?! Então, Racionais, quando ele trouxe em 2002 [a música] Nego Drama, velho, eu tenho certeza que quando nego ouviu aquilo, disse: "Caraca, velho! Sou eu mano!" (risos). Entendeu?! Talvez, não tenha entendido o [CD] "Sobrevivendo no Inferno", talvez, não tenha entendido [os CDs] "Raio X do Brasil”, "Escolha seu Caminho". Mas quando tocou Nego Drama, "Caraca, velho! Sou eu ai!" Por isso que [os/as jovens] cantam até hoje e vão cantar daqui a 20 anos, "Sou eu!", "A alma guarda o que a mente tenta esquecer" [Trecho da música]. "Pô, o que eu já vivi?!”. Então, é... Pode também... Mas é... A arte, quando ela é praticada, assim, de maneira não glamourizada, sabe?! Porque tem esses momentos, tem a arte e o artista, aquele cara do underground, mas quando a arte está aqui ó [no chão], né?! Que nem quando a gente fala de cultura, né?! Vou cultivar... (depoimento de Mano Réu).

De acordo com Frederico (2005, p. 115), "a arte, portanto, educa o homem fazendo-o transcender a fragmentação produzida pelo fetichismo da sociedade mercantil". O sujeito, fragmentado por meio das rela- 
ções no/do mercado, não mergulha na realidade, e, sim, afoga-se na aspereza da vida cotidiana. Tudo lhe parece igual, justificando-se pela falta de tempo. O sujeito perde a sensibilidade aparada de perceber-se. Por isso que " $\mathrm{A}$ arte, assim, é uma representação que nos conduz a uma realidade diferente de nosso cotidiano, pois nesta a aparência cumpre a sua função de ocultar a essência". (FREDERICO, 2013a, p. 131).

Como o cotidiano é pragmático, como "a vida cotidiana, de todas as esferas da realidade, é aquela que mais se presta à alienação" (HELLER, 1972b, p. 37), a arte transporta-nos a uma realidade diferente - não pragmática -, pois acompanha o movimento do objeto para além das aparências. Inclusive por reconhecer que a obra de arte não finaliza as reflexões, ou seja, é preciso considerar o papel e a relação da arte na cotidianidade das pessoas (FREDERICO, 2005). Sobre esse aspecto, Heller (1972a, p. 126, grifo do autor) afirma que:

Ao desfrutar da obra de arte, o receptor, tal como o criador, coloca em suspenso a sua vida cotidiana e se eleva, também ele, ao nível do plenamente humano: semelhante identificação com "a causa da humanidade" arranca-o à mediocridade da vida cotidiana e quebra a imagem do mundo fetichizado, produzida por essa vida banal. Lukács considera essa função de "desfetichização" como uma das características da obra de arte. Seus diversos momentos provocam um abalo, ao menos no âmbito da duração da experiência estética. O receptor da obra de arte não deixa de se colocar (no mais das vezes, de modo inconsciente) a questão: $\mathrm{em}$ que medida o mundo é humano? Ao se colocar essa questão: ele pensa, de um lado, no mundo da obra de arte, e, de outro, em seu próprio mundo.

Pensemos, então, na desfetichização do cotidiano, mas, também, da própria arte. Atualmente, em muitas comunidades, é o caso do distrito de Brasilândia, executam-se atividades culturais como forma de incentivar a produção cultural e de possibilitar a "inclusão social" por meio de projetos culturais. Por um lado, os vários editais oferecem condições para que artistas e coletivos da comunidade possam efetivar seus projetos. Esse aspecto é importante e apresenta contradições. O jovem Bobina acredita que: "Agora é o seguinte, é uma meritocracia também, o bagulho é meio louco, porque pouca gente vai ganhar, sacô?”. Isto é:

A gente ainda vive o momento de cultura como projeto, como coisa excepcional, tá ligado?! Ninguém vira trabalhador da cultura, tá ligado?! Eu acho que esse seria o grande lance, poder trabalhar com cultura. Aí seria ampliar mesmo lugares para apresentação, porque você teria artistas apresentando coisas. Não tem como você ter uma cena de profissionalização mesmo, com um Centro Cultural só na quebrada, não tem como, porque ia explodir de demanda, não tem como você conseguir dar essa dinâmica. Então, eu acho que é legal, identifica a galera, mas ainda não é uma proposta que busca profissionalizar mesmo, tá ligado?! Seja amplamente, acho que deveria até sair do âmbito da Política Pública de Cultura e ir pra Política Pública de Trabalho, entendeu?! Como se começasse essa... Esse trabalho da cultura. Não é uma Política do Trabalho?! Aí, você tá falando de outra coisa. Enquanto ficar só na Política Pública de Cultura a gente aí vai estar no limite, ainda (depoimento de Bobina).

\section{Juventude periférica: invisibilidade e reconhecimento}

Percebe-se que a juventude periférica tem que lutar contra uma principal imposição: a do fracasso. Em sua trajetória de vida, dentre muitas possibilidades, emergem duas. A primeira é tentar inverter a posição/ condição social que lhe é imposta. E a segunda é confirmar a certeza implicada a ela, antes mesmo de posicionarse no mundo. Em outras palavras, aceitar as "profecias" conservadoras e preconceituosas direcionadas a ela. Por isso, a ampliação de trajetórias vitais é relevante e deve-se analisar cada expressão dessa juventude, inclusive acerca das estatísticas, pois:

Tem uma coisa... Que a gente foi contra a estatística, que é do acreditar no sonho. Talvez só quando a arte mesmo... Vocêfala "Caraca, velho! Eu não vou ser feliz com outra coisa, mano”... [A arte] te impõe. E aí talvez seja o único momento que a arte te impõe alguma coisa, velho. Quando ela fala "Você não vai conseguir ser outra coisa, velho!" (risos) "Velho, se você não me fazer, você não vai conseguir ser outra coisa!" (depoimento de Mano Réu).

Acreditar no sonho e buscar condições para torná-lo realidade é uma forma de questionar as estatísticas. O jovem "conversa" com a arte. Ele pensa. A arte responde e o interpela. O sonho acaba mantendo a esperança de uma vida diferente e melhor. Uma vida que contrarie a estatística, como aquela narrada por 
Primo Preto, na introdução da música dos Racionais Mc's, intitulada Capítulo 4, Versículo 3, que trouxe à tona as questões da juventude negra, no final do séculoXX.

Em Invisible Man (Homem Invisível), de Ralph Ellison (1914-1994), publicado em 1952, é apresentada a trajetória de um jovem negro que saiu da região sul dos Estados Unidos em direção ao Harlem, em Nova York. Nessa trajetória, o jovem vivencia os desafios e as contradições de sua invisibilidade. Vivencia a luta de lidar com brancos racistas e/ou emancipados e negros radicais e/ ou conformistas, bem como as barreiras étnico-raciais e sociais. Para o jovem, "Sem luz, sou não apenas invisível, mas também desprovido de forma, e não ter consciência da própria forma é viver uma morte. Eu mesmo, depois de existir por uns vinte anos, só ganhei vida quando descobri minha invisibilidade". (ELLISON, [1952] 2013, p. 28).

Simbolicamente, pode-se, aqui, tomar a "luz" como a falta de reconhecimento do outro, ou seja, "É a generosidade do olhar do outro que nos devolve nossa própria imagem ungida de valor, envolvida pela aura da significação humana, da qual a única prova é o reconhecimento alheio" (SOARES et al, 2005, p. 206). A partir do momento em que projetamos no outro um rótulo, imediatamente produzimos o sujeito invisível, mas o que vemos no outro é o que há em nós mesmos. De acordo com Soares et al (2005, p. 175), "uma das formas mais eficientes de tornar alguém invisível é projetar sobre ele ou ela um estigma, um preconceito. Quando o fazemos, anulamos a pessoa e só vemos o reflexo de nossa própria intolerância".

As reflexões de Taylor (1994) contribuem para pensarmos que o jovem periférico também vivencia essa realidade. Ora não é reconhecido, ora é reconhecido de modo equivocado. Seja em uma ou em outra situação, ambas oferecem um tipo de reconhecimento que não é legítimo, mas acaba se legitimando nos discursos social, policial e midiático.

A intenção é favorecer a troca, o entendimento - como nos disse King Nino Brown -, pois, de todas as profissões, 0 Serviço Social é uma das que mais lida direta $\mathbf{e}$ cotidianamente com as questões apresentadas por essa arte. $\mathrm{E}$, de todas as artes, $\mathrm{a}$ cultura hip-hop está entre as que mais desenvolve ações relacionadas ao objeto de estudo e intervenção do Serviço Social. E, muitas vezes, reproduzido pelo próprio jovem, que não percebe esse processo, pois já internalizou esses discursos, teve a autoestima abalada para o fracasso ou motivada para os conflitos sociais.

Percebe-se que o reconhecimento social atribuído ao jovem periférico, num primeiro momento, é desqualificador e relacionado à violência, ao perigo, aos aspectos negativos comuns à juventude não periférica, porém, esses são imunes a essa modalidade de invisibilidade social.

\section{Considerações finais}

O percurso realizado na pesquisa demonstrou, a partir das palavras emergentes dos sujeitos entrevistados, que a cultura hip-hop tem potência para romper a "parede de vidro" (depoimento de King Nino Brown), pois, para a arte revolucionária, é preciso o "contato de pele" para alcançar o "estalo" do conhecimento (depoimento de Mano Réu). Logo, "estar e resistir no espaço", de modo a não se sentir "sufocado" (depoimento de Bobina), pode nutrir o desejo e dar condições para superar a invisibilidade social, que é um processo interminável e composto de armadilhas.

A arte, portanto, na perspectiva crítica, é capaz de superar a construção social da invisibilidade da juventude periférica, mas não a elimina totalmente, em razão da luta constante pela busca de reconhecimento humano. Eis a dimensão do "ser artístico", aquele/a mediado/a pela arte, como um caminho crítico-criativo de enfrentamento constante.

Desse modo, ficou constatado também que a arte tem mais impacto para essa juventude quando está articulada à cotidianidade desse segmento, com base em suas sociabilidades territoriais significativas de ações políticas, de expressões afetivas e de aprendizado coletivo, sendo, então, as principais interfaces identificadas na perspectiva dos processos emancipatórios e da tomada e ampliação da consciência crítica, pontos relevantes para essa juventude, bem como para a cultura hip-hop e o Serviço Social. 


\section{Referências}

ARRUDA, Daniel Péricles. Espelho dos Invisíveis: a arte no trabalho com adolescentes em cumprimento de medida socioeducativa. São Paulo: Expressão \& Arte, 2018.

BAPTISTA, Myrian Veras; BATTINI, Odária. A prática profissional do assistente social: teoria, ação, construção do conhecimento. São Paulo: Veras Editora, 2009.

ELLISON, Ralph. Homem invisível. São Paulo: José Olympio, [1952] 2013.

FREDERICO, Celso. A arte no mundo dos homens: o itinerário de Lukács. São Paulo: Expressão Popular, 2013a.

FREDERICO, Celso. Da periferia ao centro: cultura e política em tempos pós-modernos. Revista Estudos Avançados, Universidade de São Paulo (USP), v. 27, n. 79, 2013b. Disponível em: http://dx.doi.org/10.1590/S0103-40142013000300017. Acesso em: 10 dez. 2016. FREDERICO, Celso. Marx e Lukács: a arte na perspectiva ontológica. Natal: EDUFRN, 2005.

HELLER, Agnes. A estética de Georg Lukács. Revista Hora, Universidade Federal de Juiz de Fora, Ano II, n. 2, 1972a.

HELLER, Agnes. O cotidiano e a história. Rio de Janeiro: Paz e Terra, 1972b.

LÖWY, Michael; DUMÉNIL, Gérard; RENAULT, Emmanuel. 100 palavras do marxismo. São Paulo: Cortez, 2015.

LUKÁCS, Geörg. Marxismo e teoria da literatura. 2. ed. São Paulo: Expressão Popular, 2010.

MARX, Karl. Manuscritos econômico-filosóficos. São Paulo: Boitempo, 2004.

MARTINELlI, Maria Lúcia. (org.). Pesquisa qualitativa: um instigante desafio. 2. ed. São Paulo: Veras, 1999.

PORTELLI, Alessandro. Tentando aprender um pouquinho: algumas reflexões sobre a ética na história oral. Projeto História, São Paulo, n. 15 , abr. 1997.

SOARES, Luiz Eduardo; MV Bill; ATHAYDE, Celso. Cabeça de porco. Rio de Janeiro: Objetiva, 2005.

TAYLOR, Charles. Multiculturalismo: examinando a política de reconhecimento. Lisboa: Instituto Piaget, 1994.

\section{Notas}

1 Este artigo é resultado da pesquisa realizada no doutorado em Serviço Social pela Pontifícia Universidade Católica de São Paulo (PUC-SP), sob orientação da Profa. Dra. Myrian Veras Baptista (1/2013)e da Profa. Dra. Maria Lúcia Martinelli (2/2013 a 1/2017).

2 Por se tratar de estudo que envolve seres humanos, a pesquisa foi submetida à avaliação do Comitê de Ética em Pesquisa (CEP), obtendo aprovação sem restrições sob o CAAE 53640515.0.0000.5482, com o objetivo de garantir a proteção, segurança e integridade de todos os envolvidos na pesquisa, bem como do pesquisador, considerando que todos os sujeitos entrevistados autorizaram a divulgação de seus nomes e pseudônimos.

3 Vide Baptista e Battini (2009).

4 VideArruda(2018).

\section{Daniel Péricles Arruda}

pericles.daniel@unifesp.br www.vulgoelemento.com.br

Pós-doutor em Psicologia Social e Doutor em Serviço Social pela Pontifícia Universidade Católica de São Paulo (PUC-SP)

Professor do curso de graduação em Serviço Social da Universidade Federal de São Paulo (UNIFESP) e membro do Departamento de Saúde, Educação e Sociedade.

\section{UNIFESP}

Rua Silva Jardim, nº 136 - Vila Mathias

Santos - SP - Brasil

CEP: $11.015-020$

\begin{abstract}
Agradecimentos
Agradeço a todos os sujeitos entrevistados pela disponibilidade, confiança e pelos importantes depoimentos; às Profas. Dras. Myrian Veras Baptista (in memoriam) e Maria Lúcia Martinelli pelas orientações e contribuições valiosas durante o processo artesanal de produção de conhecimento; ao Conselho Nacional de Desenvolvimento Científico e Tecnológico (CNPq) pela bolsa
\end{abstract}

de estudo e demais incentivos que contribuíram para o desenvolvimento da pesquisa; e a todos aqueles/aquelas que acreditam na arte como mediação, reflexão e linguagem...

\section{Agência financiadora}

Não se aplica. 
Contribuições dos autores

Não se aplica.

Aprovação por Comitê de Ética e consentimento para parti-

cipação

Aprovado

Parecer número 1.460.163 e CAAE 53640515.0.0000.5482
Consentimento para publicação

Não se aplica. 